\title{
Klebsiella pneumoniae from Indonesian Tempeh were Genetically Different from that of Pathogenic Isolates
}

\author{
EVELINE AYU ${ }^{1}$, ANTONIUS SUWANTO $^{1,2} *$, AND TATI BARUS ${ }^{1}$ \\ ${ }^{\prime}$ Department of Biology, Faculty of Biotechnology, Universitas Katolik Atma Jaya, \\ Jalan Jenderal Sudirman 51, Jakarta 12930, Indonesia, \\ 2Department of Biology, Faculty of Mathematics and Natural Sciences, Institut Pertanian Bogor, \\ Darmaga Campus, Bogor 16680, Indonesia
}

\begin{abstract}
Tempeh is important traditional Indonesian fermented food made from soybeans employing Rhizopus oligosporus or R. microsporus. During the process of tempeh production, some bacteria from the environment and tempeh starter become an integral part of tempeh, and even have important roles in determining the final quality of tempeh it self. Several studies reported the presence of Klebsiella pneumoniae in tempeh as one of vitamin B12 producing bacteria in tempeh. However, K. pneumoniae also known as opportunistic pathogens causing pneumonia and liver abscess in human. In this study, Enterobacterial Repetitive Intergenic ConsensusPolymerase Chain Reaction (ERIC-PCR) was employed to determine genetic diversity of $K$. pneumoniae isolated from tempeh and compared them with medical isolates. The result indicated that isolates from tempeh were genetically distinct from those of medical isolates.
\end{abstract}

Key words: ERIC-PCR, Klebsiella pneumoniae, tempeh

Tempe merupakan salah satu makanan utama tradisional Indonesia yang terbuat dari kacang kedelai dengan fermentasi menggunakan cendawan Rhizopus oligosporus atau R. microsporus. Selama proses pengolahan, bakteri yang berasal dari lingkungan dan inokulum awal menjadi bagian yang tidak terpisahkan dari tempe, bahkan memiliki peranan yang penting dalam menentukan kualitas akhir pada tempe. Beberapa penelitian telah melaporkan keberadaan Klebsiella pneumoniae pada tempe sebagai salah satu bakteri penghasil vitamin B12 pada tempe. Akan tetapi, K. pneumoniae juga dikenal sebagai patogen oportunis penyebab penyakit pneumonia dan abses hati pada manusia. Pada penelitian ini, metode Enterobacterial Repetitive Intergenic ConsensusPolymerase Chain Reaction (ERIC-PCR) digunakan untuk membandingkan keragaman genetik K. pneumoniae pada tempe dibandingkan dengan isolat medis. Hasil penelitian ini menunjukkan bahwa secara genetik pneumoniae pada tempe berbeda dengan isolat medis.

Kata kunci: ERIC-PCR, Klebsiella pneumoniae, tempe

Tempeh is an indigenous Indonesian fermented food and has become an important part of the Indonesian diet for hundreds years. Tempeh is consumed in relatively large portion and can be found in a variety of types of cooking and processing methods. Excellent protein quality has made tempeh become a meat substitute and becomes popular among vegetarians (Liem et al.1977).

The process of tempeh making in Indonesia is still using conventional methods with uncontrolled condition (Barus et al. 2008). During the fermentation process, not only fungi involved but also bacteria play important roles in the formation of flavor and nutrition. Bacterial growth during tempeh production begins in the process of soybean soaking. During the fermentation process, the producers inadvertently adding bacteria so that the bacteria eventually become

*Corresponding author; Phone/Fax: +62-21-5703306/5727615 ext.450/+62-21-5719060, Email: antoniussuwanto@gmail.com an inseparable part of tempeh, and even has an important role in determining the quality of tempeh (Barus et al.2008; Seumahu etal.2013).

Several studies have reported the presence of bacteria in tempeh as Klebsiella pneumoniae and Citrobacter freundii (Keuth and Bisping 1994), and also bacteria of the phylum Proteobacteria and Firmicutes (Seumahu et al. 2012) which are reported as bacteria producing vitamin $\mathrm{B}_{12}$ in tempeh. Other contaminants such as Brevibacterium epidermidis and Micrococcus luteus known to play a role in the formation of antioxidants in tempeh (Klus and Barz 1995). Furthermore, bacteria in tempeh is also known as one of the factors that play a role in the formation of a bitter taste in tempeh (Barus et al. 2008). A diverse array of lactid acid bacteria and yeasts also play important role in Indonesian tempeh production (Efriwati et al.2013).

$K$. pneumoniae which is included in family Enterobacteriaceae is also known both of causing 
pneumonia disease, an acute infection that attacks the alveoli (Gori et al. 1996) and liver abscess in human (Wang et al. 1998). Therefore, the study of genetic diversity is important for the identification and characterization of bacterial pathogenicity (Rademaker and de Bruijn 1997). One of the many molecular techniques for the study of genetic diversity is Enterobacterial Repetitive Intergenic Consensus (ERIC)-PCR. ERIC sequences are short sequences, which is $126 \mathrm{bp}$ long, with sequences that are conserved as internal repeat and as non-coding sequences (Lupski et al. 1992). This technique is often used because it is simple, rapid, reproducible, and discriminative (Olive et al. 1999) and has been successfully analyzed the diversity of different types of bacteria, such as Mycobacterium tuberculosis (Sechi et al. 1998) and Vibrio parahaemolyticus (Khan et al. 2002). ERICPCR has also been used to analyzed genetic diversity of Klebsiella spp. isolated from tempeh (Barus et al. 2013), as well as to study genetic heterogeneity of many types of Vibrio cholerae (Waturangi et al. 2012).

\section{MATERIALS AND METHODS}

This research was conducted in Research Laboratory, Faculty of Biotechnology, Atma Jaya Catholic University of Indonesia from May to December 2013.

Medical isolates of $K$. pneumoniae. Four medical isolates ware used for comparison with $K$. pneumoniae from tempeh, i.e. K. pneumoniae ATCC BAA-2146, $K$. pneumoniae subsp. pneumoniae ATCC 10031, K. pneumoniae ATCC 35657, and one K. pneumoniae isolate originated from pneumonia patient, named as FK isolate, collection of Department of Microbiology, Faculty of Medicine, Atma Jaya Catholic University.

$K$. pneumoniae isolates from Tempeh. Tempeh EMP and WJB was produced in Bogor, West Java, Indonesia (Barus et al. 2008). A $10 \mathrm{~g}$ of fresh tempeh was placed into $90 \mathrm{~mL}$ of sterile physiological salt $0.85 \%(\mathrm{w} / \mathrm{v}) \mathrm{NaCl}$ and homogenized in orbitar shaker (Yih Der) at a speed of $24 \mathrm{x} g$ for one min. Dilution was made from $10^{-1}$ until $10^{-6}$ and a $100 \mu \mathrm{L}$ from dilution of $10^{-4}, 10^{-5}$, and $10^{-6}$ was spread on Eosin Methylene Blue (EMB) Agar (Oxoid) and incubated overnight at $37^{\circ} \mathrm{C}$. A single purple mucoid colony was typical character of K. pneumoniae. These colonies were further analyzed by cultivating them on Simmons' Citrate Agar (SCA) (Difco), and incubated at $37{ }^{\circ} \mathrm{C}$ for $24 \mathrm{~h}$. Tempeh sampling were conducted twice, i.e. August and October 2013. Klebsiella sp. 135 isolated from tempeh was used for control (Maysella 2010).

Analysis of 16S rRNA Genes. Suspected blue colonies on Simmons' Citrate Agar were further verified using sequencing of genes encoding $16 \mathrm{~S}$ rRNA. The whole cells from single colonies on plates were used directly in PCR reaction as described by Rademaker and de Bruijn in 1997. The 16S rRNA gene was amplified employing a PCR machine (Applied Biosystems, 2720 Thermal Cycler) using primer 63f (5'- CAGGCCTAACACATGCAAGTC3') and 1387r (5'- GGGCGGWT GTACAAGGC -3') (Marchesi et al. 1998). Total PCR volume was $50 \mu 1$ containing $2 \mu \mathrm{L}$ DNA template, $25 \mu \mathrm{L}$ GoTaq Green ${ }^{\circledR}$ Master Mix (Promega), $2 \mu \mathrm{L}$ primer forward dan reverse $\left(25\right.$ pmol $\left.\mu \mathrm{L}^{-1}\right)$ dan $19 \mu \mathrm{L}$ nuclease free water. The PCR protocol was as follows: initial denaturation at $94{ }^{\circ} \mathrm{C}$ for $5 \mathrm{~min}$, denaturation at $92{ }^{\circ} \mathrm{C}$ for $30 \mathrm{~s}$, annealing at $62{ }^{\circ} \mathrm{C}$ for $30 \mathrm{~s}$, elongation at $72^{\circ} \mathrm{C}$ for $30 \mathrm{~s}$, and post extention at $72{ }^{\circ} \mathrm{C}$ for $7 \mathrm{~min}$. The cycle was repeated for 30 times. A $5 \mu \mathrm{L}$ of PCR amplification products were further verified by electrophoresis in $1 \%$ agarose (Bioline) in 1x TAE buffer for $60 \mathrm{~min}, 80$ $\mathrm{V}$. Sequencing of PCR products were performed in Macrogen Inc., Korea, and were analyzed employing a program SeqTrace. Sequencing results were compared to the database with the Basic Local Alignment Search Tool (BLAST) program which is provided by National Centre of Biotechnology Information (NCBI).

Genetic Profiling of K. pneumoniae Isolates. 13 bacterial isolates were identified as $K$. pneumoniae from EMP tempeh and 10 isolates from WJB tempeh. A total PCR volume used was $25 \mu \mathrm{L}$ containing 12.5 $\mu \mathrm{L}$ GoTaq Green ${ }^{\circledR}$ Master Mix (Promega), $1 \mu \mathrm{L}$ of 25 pmol ERIC1R (5'-ATGTAAGCTCCTGGGGATTCA C-3'), $1 \mu$ L of 25 pmol ERIC2F (5'-AAGTAAGTGAC TGGGGTGAGCG-3')Give references for the primers (Versalovic et al. 1991), 9.5 $\mu \mathrm{L}$ nuclease free water, and $1 \mu \mathrm{L}$ DNA template which was obtained directly from the isolates using a sterile toothpick. The PCR protocol was as follows: initial denaturation at $95^{\circ} \mathrm{C}$ for $7 \mathrm{~min}$, denaturation at $95^{\circ} \mathrm{C}$ for $30 \mathrm{~s}$, annealing at $49^{\circ} \mathrm{C}$ for 1 min, elongation at $65^{\circ} \mathrm{C}$ for $8 \mathrm{~min}$, and post extention at $65^{\circ} \mathrm{C}$ for 16 min (Applied Biosystems, 2720 Thermal Cycler). The PCR cycle was used 30 times. A $5 \mu \mathrm{L}$ of PCR products was verified by electrophoresis for 90 min and $70 \mathrm{~V}$, on $1 \%$ agarose in $1 \mathrm{x}$ TAE buffer. Formed band profiles were observed under the UV transilluminator. Formed band profiles were then compared as biner number and analyzed using FreeTree (Hampl et al. 2001) and TreeView to construct a phylogenetics tree (http://taxonomy.zoology.gla.ac.uk/ 
$\operatorname{rod} /$ treeview.html.

\section{RESULTS}

Isolation of $K$. pneumoniae. A total of 58 bacterial isolates (Table 1) were isolated from EMP and WJB tempeh. The bacterial colonies were purple in the center of colony, mucoid, and rounded shape on EMB medium. The colonies of these isolates changed from green to blue on Simmons'Citrate medium, which is specific character of Klebsiella sp.

Fig 1A and 1B showed hypermucoviscocity of $K$. pneumoniae ATCC35657 or FK colonies when touched with inoculating loop. However, colonies of K. pneumoniae from EMP (Fig 1C) and WJB tempeh (Fig 1D) did not show hypermucoviscosity. This character showed significant phenotypic difference between tempeh and those of medical isolates.

Analysis of $16 \mathrm{~S}$ rRNA Genes. A total of 18 isolates from the EMP tempeh and 25 isolates from WJB tempeh were selected for further amplification of genes encoding 16S rRNA. Based on 16S rRNA gene sequence alignments with the NCBI database, $K$. pneumoniae were identified in 13 isolates obtained from EMP tempeh and 10 isolates from WJB tempeh (Table 1). The other microorganisms were found from EMP tempeh based on 16S alignment analysis were: Klebsiella sp., Rhizobium sp., and Enterobacter sp. while Bacterium sp., Klebsiella sp., and Cronobacter sakazakii were isolated from WJB tempeh.

Genetic Profiling of $K$. pneumoniae Isolates. A total 23 isolates which were identified as $K$. pneumoniae were further subjected to ERIC-PCR analysis in order to compare their genetic diversity from those of medical isolates. ERIC-PCR of 13 isolates of $K$. pneumoniae from EMP tempeh showed a similar pattern (Fig 2). The ERIC-PCR profiles of medical isolates showed a diverse patterns but distinctively different from tempeh isolates. This result indicated that $K$. pneumoniae presence in tempeh was not the same as pathogenic K. pneumoniae. Similar result were also found when we analysed isolates from WJB tempeh (Fig 3) which showed different ERICPCR profiles from the medical isolates. Although genetic profiles of K. pneumoniae isolates in WJB tempeh were more varied than EMP tempeh, we found noi dentical profiles when compared to those of medical isolates.

The resulting electrophoresis band profiles were further converted into binary data matrix. The results were used to construct a phylogenetic tree using FreeTree program and TreeView. Fig 4 showed the genetic relationship of $K$. pneumoniae isolated from EMP tempeh. Based on this analysis, the medical isolates clustered into a separate and distict group. Tempeh isolates formed two groups, the first one contains isolates which have similar ERIC profiles, i.e., I EMP16, I EMP13, I EMP9, I EMP8, I EMP5, I EMP4, and I EMP. The other group contains of I EMP1, II EMP5, II EMP2, II EMP4, II EMP1, and II EMP3. Isolates from WJB tempeh formed a separate group under one branch except one isolate, I WJB2 (Fig 5). Again, in this analysis, the medical isolates formed a separate group outside the branches which contained isolates from WJB.

\section{DISCUSSION}

K. pneumoniae presence in both of tempeh samples (EMP and WJB) and consistantly exist from the first

Table 1 Klebsiela pneumoniae from fresh tempeh

\begin{tabular}{cccccc}
\hline Tempeh sample & $\begin{array}{c}\text { Number of } \\
\text { sampling }\end{array}$ & EMB agar & SCA & $\begin{array}{c}\text { Number of Isolates } \\
\text { Sequencing of } \\
16 \text { S rRA }\end{array}$ & $\begin{array}{c}\text { DNA Sequence } \\
\text { Alignment } \\
\text { (K. pneumoniae) }\end{array}$ \\
\hline EMP & I & 18 & 18 & 10 & 8 \\
Total of EMP & II & 8 & 8 & 8 & 5 \\
WJB & I & 17 & 10 & 18 & 13 \\
Total of WJB & II & 15 & 15 & 10 & 7 \\
\hline Grand Total & & 32 & 25 & 26 & 15 \\
\hline
\end{tabular}



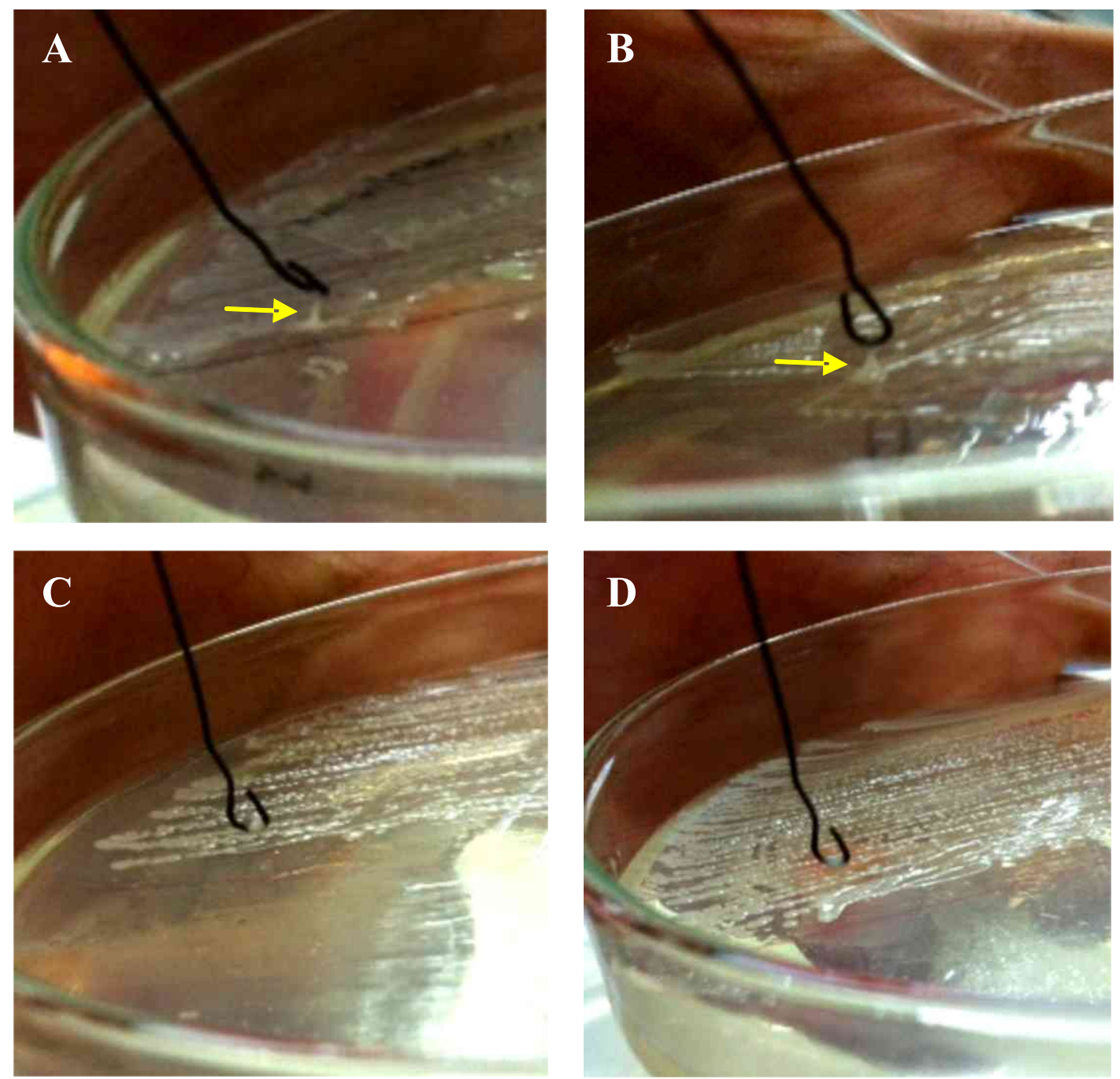

Fig 1 The phenotype of K. pneumoniae ATCC 35657 (A), FK isolate (B), K. pneumoniae from EMP(C), and WJB tempeh (D).

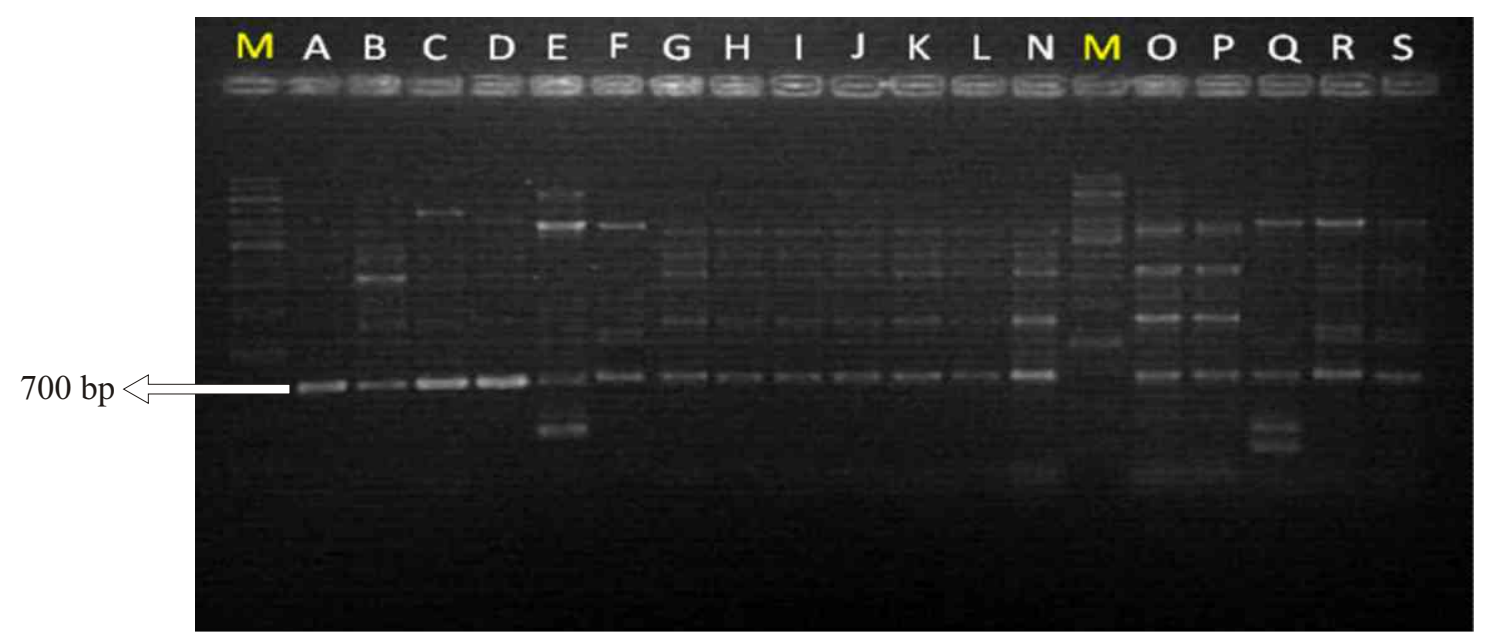

Fig 2 ERIC-PCR from K. pneumoniae from EMP tempeh, ie. (M) Molecular markers, (A) ATCC 10031, (B) ATCC 2014, (C) ATCC 35657, (D) FK, (E) Klebsiella sp. 135, (F) I EMP1, (G) I EMP3, (H) I EMP4, (I) I EMP5, (J) I EMP8, (K) I EMP9, (L) I EMP13, (N) I EMP16, (O) II EMP1, (P) II EMP2, (Q) II EMP3, (R) II EMP4, and (S) II EMP5.

and second sampling of each of these tempeh samples. The presence of $K$. pneumoniae in tempeh have been reported before (Keuth et al. 1994, Barus et al. 2008).
Growth of $K$. pneumoniae on EMB medium showed distinctive colony morphology, which were dark purple in the center, mucoid, and rounded shape. 


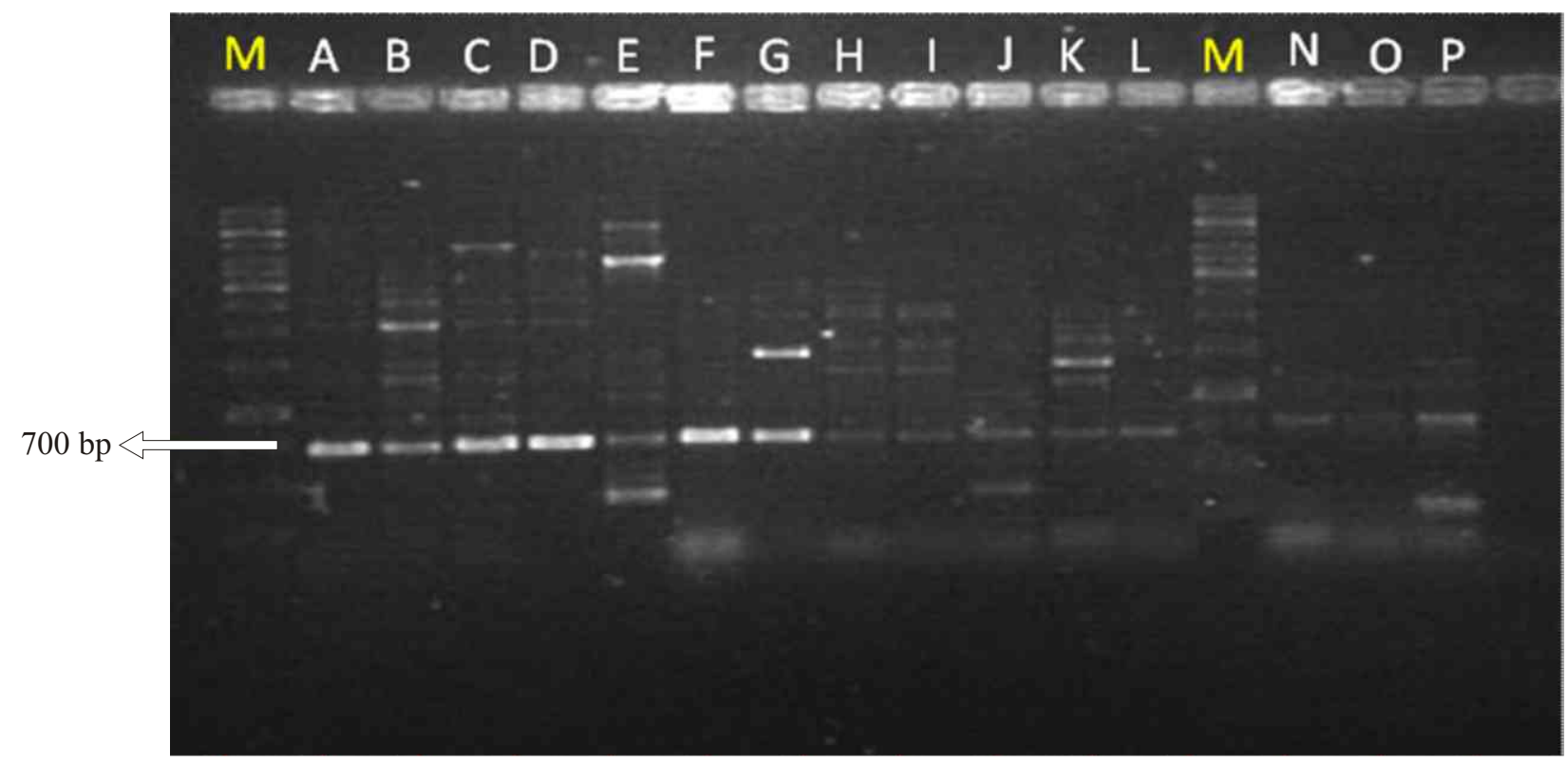

Fig 3 ERIC-PCR profiles of K. pneumoniae from WJB tempeh, ie. (M) Molecular markers, (A) ATCC 10031, (B) ATCC 2014, (C) ATCC 35657, (D) FK, (E) Klebsiella sp. 135, (F) I WJB1, (G) I WJB2, (H) I WJB3, (I) I WJB4, (J) I WJB5, (K) I WJB6, (L) I WJB16, (N) II WJB3, (O) II WJB5, and (P) II WJB8.

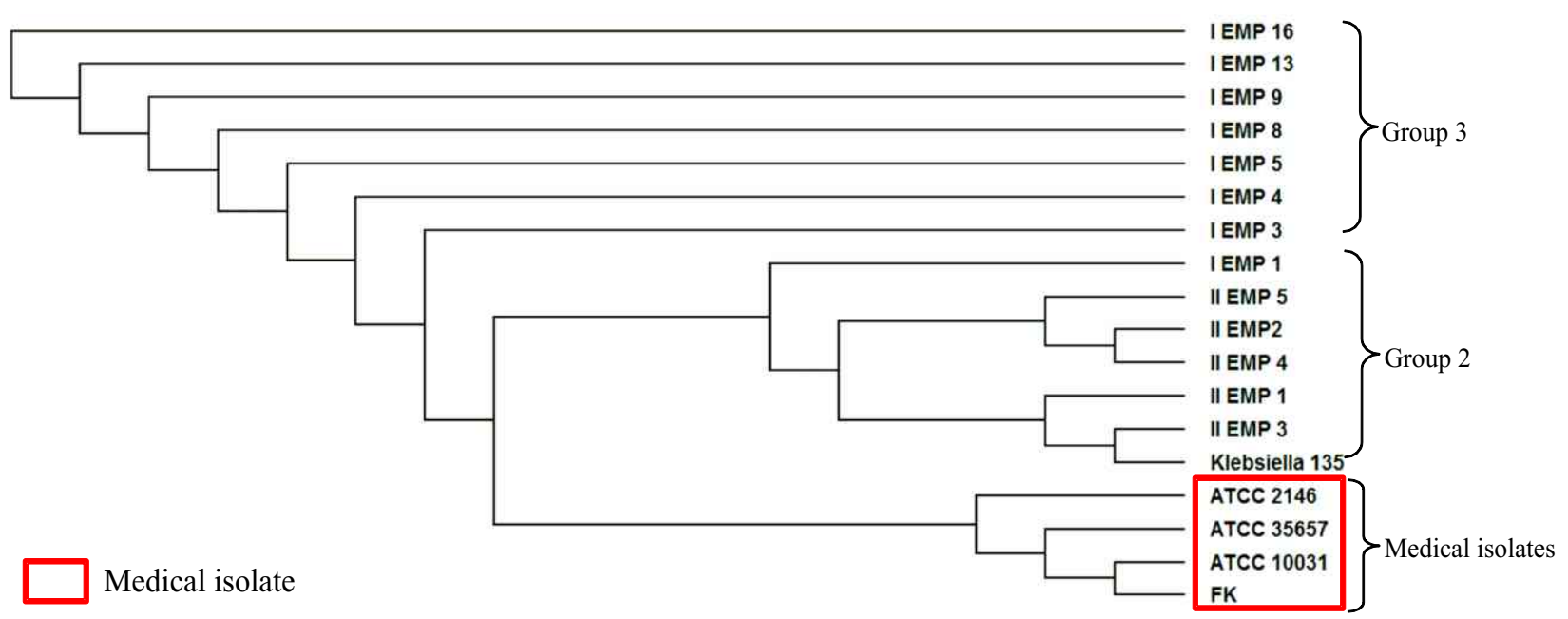

Fig 4 Philogenetic tree generated from ERIC-PCR profiles of $K$. pneumoniae isolated from EMP tempeh.

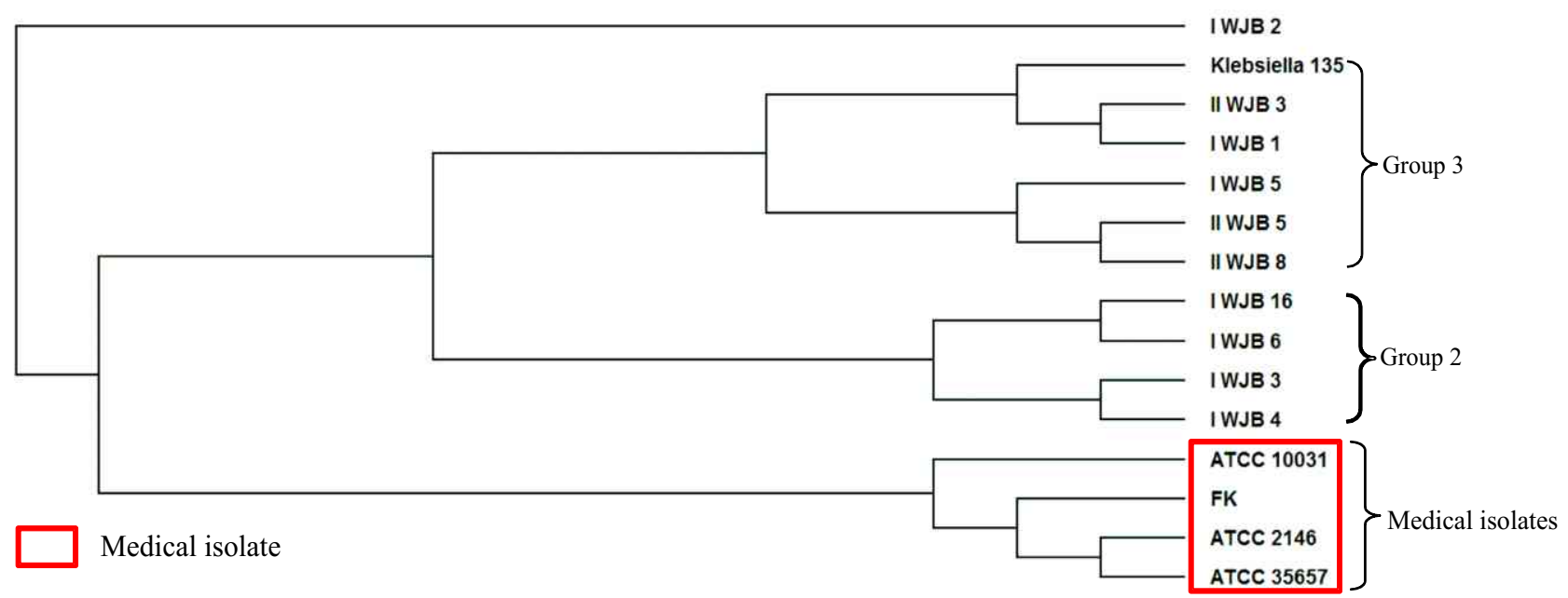

Fig 5 Philogenetic tree generated from ERIC-PCR profiles of $K$. pneumoniae isolated from WJB tempeh. 
Fig1showed the phenotype difference tha the colonies of medical isolates showed more sticky on solid media than those isolated from tempeh. Mutation in magA is one of the factors that mutants lost the hypermucoviscosity phenotype and became susceptible tophagocytes and a virulent to mice (Fang et al. 2004).

$16 \mathrm{~S}$ rRNA gene sequences are the most common house keeping genetic marker used for identifying bacteria in the laboratory (Janda et al. 2007). Although 16S rRNA gene (approximately $1500 \mathrm{bp}$ ) is large enough for bioinformatics purposes, but usually it is not reliable for intra-strain differentiation. For example, Escherichia coli O104: H4 that is known pathogenic as well as isolate in recent out breaking Germany (Mellmann et al. 2011) were confirmed only as $E$. coli based on $16 \mathrm{~S}$ DNA sequence analysis.

We confirmed colonies obtained from tempeh samples as $K$. penumoniae based on 16S DNA sequence analysis before subjected them for ERICPCR analysis to reveal intra-species genetic diversity (Barus et al.2013).

In this study, ERIC-PCR method has been successfully employed to differentiate genetic profiles of $K$. pneumoniae isolated from tempeh and those of medical isolates. The ERIC-PCR profiles of $K$. pneumoniae from EMP tempeh (Fig2) and WJB tempeh (Fig3) were different from those of medical isolates. Keuth and Bispingin 1994 reported that $K$. pneumoniae isolated from Indonesian tempeh were negative for three known enterotoxins, i.e. Shiga-like toxin SLTIIA, heat-labil enterotoxin LTIh, and heatstable enterotoxin STIh. Therefore, intraspecies genetic diversity within K. pneumoniae might reflect different phenotypes which could make the pathogenic or non-pathogenic.

The phylogenetic analysis showed two separate clusters representing $\mathrm{K}$. pneumoniae from tempeh and the medical isolates. The phylogenetic trees generated from EMP tempeh showed unambiguously that tempeh isolates were genetically different from pathogenic $K$. pneumoniae (Fig4). That figure showed three main groups were formed from tempeh isolates, while the medical isolates were clearly separated in a different group. Similar result was also obtained from isolates derived fromWJB tempeh (Fig 5)

Our results suggested that $K$. pneumoniae isolates inIndonesian tempeh could be a distinctive nonpathogenic group of this species. This is also in line with the facts that tempeh production and consumption have been practiced in Indonesia for centuries and, to our knowledge, there is no single report on infectious disease associated with K. pneumoniae in tempeh. On the other hand, their presence in tempeh might be beneficial due to their ability to synthesize vitamin B12 and their immunomodulatory effects in human.

To conlude tempeh produced in Indonesia naturally harbors $K$. pneumoniae with unique genomic profiles. K. pneumoniae from tempeh samples in this study showed that they were genetically different from isolates known to be pathogenic to human.

\section{ACKNOWLEDGMENT}

This work was supported by DANA DIPA IPB (code : 2013.089.521219). We also acknowlegde the Department of Microbiology, Faculty of Medicine, Universitas Katolik Atma Jaya for the FK isolate.

\section{REFERENCES}

Barry T, Colleran G, Glennon M, Dunican LK, Gannon F. 1991. The $16 \mathrm{~s} / 23 \mathrm{~s}$ ribosomal spacer region as a target for DNA probes to identify Eubacteria. PCR Methods Appl. 1:51-56. doi:10.1101/gr.1.1.51.

Barus T, Hanjaya I, Sadeli J, Lay BW, Suwanto A, Yulandi A. 2013. Genetic diversity of Klebsiella spp. isolated from tempe based on enterobacterial repetitive intergenic consensus-polymerase chain reaction (ERIC-PCR). HAYATI J Biosci. 20(4):171-176. doi:10.4308/hjb. 20. 4.171.

Barus T, Suwanto A, Wahyudi AT, Wijaya H. 2008. Role of bacteria in tempeh bitter taste formation: microbiological and molecular biological analysis based on 16S rRNA gene. Microbiol Indones. 2(1):1721. doi:10.5454/mi.2.1.4.

Efriwati, Suwanto A, Rahayu G, Nuraida L. 2013. Population dynamics of yeasts and lactic acid bacteria (LAB) during tempeh production. HAYATI J Biosci. 20(2):57-64. doi:10.4308/hjb.20.2.57.

Fang CT, Chuang YP, Shun CT, Chang SC, Wang JT. 2004. A novel virulence gene in Klebsiella pneumoniae strains causing primary liver abscess and septic metastatic complications. J Exp Med. 199(5):697-705. doi:10.108 4/jem.20030857.

Gori A, Espinasse F, Deplano A, Nonhoff C, Nicolas MH, Struelens MJ. 1996. Comparison of pulsed-field gel electrophoresis and randomly amplified DNA polimorphism analysis for typing extended-spectrum$\beta$-lactamase-producing Klebsiella pneumoniae. J Clin Microbiol. 34(10):2448-2453.

Hagedorn S and Kaphammer B. 1994. Microbial biocatalysis in the generation of flavor and fragrance chemicals. Ann Rev Microbiol. 48:773-800. doi:10.1146/annurev.mi.48.100194.004013.

Hampl V, Pavlicek A, Flegr J. 2001. Construction and bootstrap analysis of DNA fingerprinting-based phylogenetic trees with the freeware program 
FreeTree: application to trichomonad parasites. Int J Sys Evol Microbiol. 51(3):731-735. doi:10.1099/0020 7713-51-3-731.

Janda JM and Abbott SL. 2007. 16S rRNA gene sequencing for bacterial identification in the diagnosis library: pluses, perils, and pitfalls. J Clin Microbiol. 45(9):27612784. doi:10.1128/JCM.01228-07.

Keuth S and Bisping B. 1994. Vitamin $\mathrm{B}_{12}$ production by Citrobacter freundii or Klebsiella pneumoniae during tempeh fermentation and proof of enterotoxin absence by PCR. Appl Environ Microbiol. 60(5):1495-1499.

Khan AA, McCarthy S, Wang RF, Cerniglia CE. 2002. Characterization of United States outbreak isolates of Vibrio parahaemolyticus using enterobacterial repetitive intergenic consensus (ERIC) PCR and development of a rapid PCR method for detection of O3:K6 isolates. FEMS Microbiol. 206(2):209-214. doi:10.1111/j.1574-6968.2002.tb11011.x.

Klus K and Barz W. 1995. Formation of polyhydroxylated isoflavones from the soybean seed isoflavones daidzein and glycitein by bacteria isolated from tempeh. Archives Microbiol. 164(6):428-434. doi:10.1007/BF02529741.

Lane DJ, Pace B, Olsen GC, Stahl DA, Sogin ML, Pace NR. 1985. Rapid determination of 16 S rRNA sequences for phylogenetic analyses. PNAS 82(20):6955-6959. doi:10.1073/pnas.82.20.6955.

Liem ITH, Steinkraus KH, Cronk TC. 1977. Production of vitamin $\mathrm{B}_{12}$ in tempeh, a fermented soybean food. Appl Environ Microbiol. 34(6):773-776.

Lupski JR and Weinstock GM. 1992. Short, interspersed repetitive DNA sequences in prokaryotic genomes. J Bacteriol. 174(14):4525-4529.

Marchesi JR, Sato T, Weightman AJ, Martin TA, Fry JC, Hiom SJ, Wade WG. 1998. Design and evaluation of useful bacterium-specific PCR primers that amplify genes coding for bacterial 16S rRNA. Appl Environ Microbiol. 64(2):795-799.

Maysella. 2010. Isolation and genetic diversity analysis of Klebsiella poneumoniae in tempe based on 16S rRNA encoding gene [Thesis]. Jakarta (ID): Faculty of Biotechnology, Atma Jaya Catholic University of Indonesia.

Meacham KJ, Zhang L, Foxman B, Bauer RJ, Marrs CF. 2003. Evaluation of genotyping large numbers of Escherichia coli isolates by enterobacterial repetitive intergenic consensus-PCR. J Clin Microbiol. 41(11):5224-5226. doi:10.1128/JCM.41.11.5224-5226.2003.

Mellmann A, Harmsen D, Cummings CA, Zentz EB, Leopold SR, Rico A, Prior K, Szczepanowski R, Ji Y,
Zhang W, McLaughin SF, Henkhaus JK, Leopold B, Brelaszewka M, Prager R, Brzoska PM, Moore RL, Guenther S, Rothberg JM, Karch H. 2011. Prospective genomic characterization of the German Enterohemorrhagic Escherichia coli O104:H4 outbreak by rapid next generation sequencing technology. PLoS ONE. 6(7):e22751. doi:10.1371/journal.pone.0022751.

Nout MJR and Kiers JL. 2005. Tempe fermentation, innovation and functionality: update into the third millenium. J Appl Microbiol. 98(4):789-805. doi:10.1111/j.1 365-2672.2004.02471.x.

Olive DM and Bean P. 1999. Principles and applications of methods for DNA-based typing of microbial organisms. J Clin Microbiol. 37(6):1661-1669.

Rademaker JLW and de Bruijn FJ. 1997. Characterization and classification of microbes by REP-PCR genomic fingerprinting and computer assisted pattern analysis, p.151-171. DNA Markers: Protocols, Applications and Overviews. New York: Wiley and Sons.

Sechi LA, Zanetti S, Dupré I, Delogu G, Fadda G. 1998. Enterobacterial repetitive intergenic consensus sequences as molecular targets for typing of Mycobacterium tuberculosis strains. J Clin Microbiol. 36(1):128-132.

Seumahu CA, Suwanto A, Rusmana I, Solihin DD. 2012. Comparison of DNA extraction methods for microbial community analysis in Indonesian tempeh employing amplified ribosomal intergenic spacer analysis. HAYATI J Biosci. 19(2):93-98. doi:10.4308/hjb.19.2.93.

Seumahu CA, Suwanto A, Rusmana I, Solihin DD. 2013. Bacterial and fungal communities in tempeh as reveal by amplified ribosomal intergenic sequence analysis. HAYATI J Biosci. 20(2):65-71. doi:10.4308/hjb.20.2.65.

Versalovic J, Koeuth T, Lupski JR. 1991. Distribution of repetitive DNA sequences in eubacteria and application to fingerprinting of bacterial genomes. Nucleic Acids Res. 19(24):6823-6831. doi:10.1093/nar/19.24.6823.

Wang JH, Liu YC, Lee SS, Yen MY, Chen YS, Wang JH, Wann SR, Lin HH. 1998. Primary liver abscess due to Klebsiella pneumoniae in Taiwan. Clin Infect Dis. 26(6):1434-1438. doi:10.1086/516369.

Waturangi DE, Joanito I, Yogi Y, Thomas S. 2012. Use of REP- and ERIC-CPR to reveal genetic heterogeneity of Vibrio cholerae from edible ice in Jakarta, Indonesia. Gut Pathog. 4:2. doi:10.1186/1757-4749-4-2. 